\title{
The healthiness of spring triticale in cereal-legume mixtures
}

\section{Zdrowotność pszenżyta jarego w mieszankach zbożowo-strączkowych}

\author{
Marcin Kozak ${ }^{1}$, Wiesław Wojciechowski ${ }^{2}$, Marta Ćwiertniewska $^{1}$, Monika Białkowska ${ }^{1}$
}

\begin{abstract}
Summary
Nowadays, when sustainable agriculture has become meaningful, legume crops, which provide high protein content feed and improve soil properties are of special value. A well-balanced cereal-legume mixtures brings many profits, such as better productivity or ecological benefits as improvement of cereal healthiness. In the aspect of the crop structure in Poland dominated by cereals this issue seems to be of a great importance. The aim of the experiment was to determine the health condition of spring triticale in cereallegume mixtures with diversified share of both components. Spring triticale cultivar Milkaro was sown with two cultivars of yellow lupine - Dukat and Mister. Pure sowing of triticale was compared with 50, 73, 86 and 94 share of triticale in mixture. A positive influence of legume participation in mixtures on spring triticale healthiness was shown. No significant influence on the tested properties of yellow lupine cultivars was stated.
\end{abstract}

Key words: spring triticale; cereal-legume mixtures; healthiness

\section{Streszczenie}

W dobie rolnictwa zrównoważonego szczególnego znaczenia nabiera uprawa roślin strączkowych, które oprócz dostarczania wysokobiałkowej paszy, poprawiają właściwości gleby. Odpowiednio dobrana mieszanka zbożowo-strączkowa może oprócz efektów produkcyjnych przynieść znaczne korzyści ekologiczne, chociażby poprawę zdrowotności roślin zbożowych. Jest to ważne, gdyż od kilku lat udział zbóż w strukturze zasiewów w Polsce stanowi około trzy czwarte całkowitej powierzchni upraw. Celem badań było określenie zdrowotności pszenżyta jarego w mieszankach zbożowo-strączkowych z różnym udziałem obu komponentów. Pszenżyto jare odmiany Milkaro wysiewano z dwoma odmianami łubinu żółtego: Dukat i Mister. Stosowano siew czysty pszenżyta oraz mieszany z 50, 73, 86 i $94 \%$ udziałem pszenżyta. Wykazano korzystne oddziaływanie udziału rośliny strączkowej w mieszance z pszenżytem jarym na jego zdrowotność. Nie wykazano natomiast istotnego wpływu na badane cechy odmiany łubinu żółtego.

Słowa kluczowe: pszenżyto jare; mieszanki zbożowo-strączkowe; zdrowotność

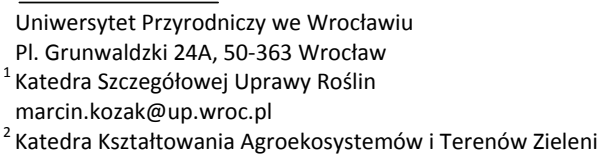




\section{Wstęp / Introduction}

Dane Głównego Urzędu Statystycznego (GUS 2012) wskazują na niezmienną od kilku lat, dominację zbóż w strukturze zasiewów na terenie Polski. Częsta uprawa zbóż po sobie skutkuje negatywnymi efektami, wyrażającymi się między innymi, wzrostem zachwaszczenia, zmniejszeniem poziomu plonowania, czy też występowaniem chorób roślin.

Niezmiernie ważnym elementem rolnictwa zrównoważonego jest uprawa płodozmianowa, która obok poprawy właściwości gleby i stabilizacji plonowania może przyczyniać się do ograniczenia zachwaszczenia oraz występowania chorób roślin uprawnych, w tym głównie zbóż (Małecka i wsp. 2010; Parylak i wsp. 2010; Paluch i Parylak 2011). Szczególne znaczenie w zmianowaniu powinny zajmować rośliny strączkowe, które będąc podstawowym składnikiem surowcowym cennej paszy wysokobiałkowej mogą również poprawiać stan fitosanitarny łanu i gleby. Siew czysty tych gatunków jest jednak w praktyce często zawodny, dlatego większego znaczenia powinny nabrać w niedalekiej przyszłości mieszanki zbożowo-strączkowe. Należy przypuszczać, że ten sposób uprawy może służyć nie tylko poprawie ich produkcyjności, ale również polepszać zdrowotność uprawianych komponentów.

W dostępnej literaturze przedmiotu jest niewiele aktualnych danych dotyczących tego zagadnienia, chociaż każda uprawa roślin w mieszankach gatunków lub Mieszaninach odmian najczęściej prowadzi do ograniczenia występowania chorób grzybowych, między innymi mączniaka prawdziwego (Michalski i wsp. 1996; Tratwal i wsp. 2012).

Celem badań było określenie wpływu różnych udziałów nasion łubinu żółtego i ziaren pszenżyta jarego w materiale siewnym na zdrowotność pszenżyta.

\section{Materiały i metody / Materials and methods}

Eksperyment polowy przeprowadzono w latach 20102012, na polach doświadczalnych Katedry Szczegółowej Uprawy Roślin Uniwersytetu Przyrodniczego we Wrocławiu w Pawłowicach. Mieszanki komponowano w oparciu o jedną odmianę pszenżyta jarego (Milkaro) i dwie odmiany łubinu żółtego (Dukat i Mister) o poniżej podanych udziałach roślin (tab. 1).

Tabela 1. Udział komponentów w mieszance

Table 1. Share of components in the mixtures

\begin{tabular}{|c|c|c|}
\hline \multicolumn{2}{|c|}{$\begin{array}{l}\text { Liczba wysianych nasion/ziaren na } 1 \mathrm{~m}^{2} \\
\text { Number of sown seeds/grains per } 1 \mathrm{~m}^{2}\end{array}$} & \multirow{2}{*}{$\begin{array}{c}\text { Udział } \\
\text { pszenżyta } \\
\text { Share of } \\
\text { triticale } \\
{[\%]}\end{array}$} \\
\hline $\begin{array}{c}\text { Łubin żółty } \\
\text { (Dukat lub Mister) } \\
\text { Yellow lupine } \\
\text { (Dukat or Mister) }\end{array}$ & $\begin{array}{l}\text { pszenżyto jare (Milkaro) } \\
\text { spring triticales (Milkaro) }\end{array}$ & \\
\hline 80 & 80 & 50 \\
\hline 60 & 160 & 73 \\
\hline 40 & 240 & 86 \\
\hline 20 & 320 & 94 \\
\hline 0 & 400 & 100 \\
\hline
\end{tabular}

Ścisłe doświadczenie polowe założono w trzech powtórzeniach, metodą losowanych podbloków (splitplot), na dwa czynniki zmienne (I - odmiany łubinu żółtego: Dukat, Mister; II - zróżnicowany udział komponentów mieszanki zbożowo-strączkowej). Powierzchnia pojedynczego poletka do zbioru wynosiła $15 \mathrm{~m}^{2}$. Doświadczenie prowadzono na glebie lekkiej, zakwalifikowanej do $\mathrm{V}$ klasy bonitacyjnej. Przed siewem zastosowano nawożenie mineralne $\mathrm{w}$ następujących dawkach: $30 \mathrm{~kg} / \mathrm{ha}$ azotu (dodatkowo $30 \mathrm{~kg} / \mathrm{ha} \mathrm{w}$ siewie czystym pszenżyta w fazie strzelania w źdźbło), $60 \mathrm{~kg} / \mathrm{ha}$ fosforu i $120 \mathrm{~kg} / \mathrm{ha}$ potasu. Ze względu na charakter doświadczenia nie stosowano fungicydów w okresie wegetacji roślin.

Ocenę porażenia korzeni i podstawy źdźbła pszenżyta jarego przez patogeny wywołujące kompleks chorób podstawy źdźbła przeprowadzono w fazie dojrzałości mlecznej ziarna (BBCH 75). W tym celu, z każdego poletka, losowo wykopywano po 35 roślin. Wydzielono pięć klas porażenia korzeni: 0 - zdrowe; $1-1-10 \% ; 2-11-30 \% ; 3-31-60 \%$ i 4 - powyżej $60 \%$ porażonej powierzchni korzeni oraz cztery klasy porażonej powierzchni podstawy źdźbła: 0 zdrowe; 1 - porażone słabo (do 30\%); 2 - porażone średnio (do 60\%) i 3 - porażone w stopniu silnym (powyżej $60 \%$ ). Indeks porażenia obliczono metodą TownsendaHeubergera (1943).

Uzyskane dane zostały opracowane statystycznie na poziomie istotności $\alpha=0,05$ za pomocą programu AWA (Bartkowiak 1978).

\section{Wyniki i dyskusja / Results and discussion}

Rozpoczęcie prac polowych w okolicach Wrocławia w 2010 roku było możliwe w III dekadzie marca. Stąd w I dekadzie kwietnia, w warunkach dość silnego uwilgotnienia gleby i jednocześnie niskich średnich dobowych temperatur powietrza wykonano siew komponentów mieszanek zbożowo-strączkowych. W fazie wschodów roślin, tj. II i III dekadzie kwietnia odnotowano kolejny okres opadów $(35,7 \mathrm{~mm})$, które następnie nasiliły się w maju $(140,7 \mathrm{~mm})$. Początek kłoszenia pszenżyta oraz kwitnienia łubinu żółtego przypadły na okres o ustabilizowanych warunkach pogodowych, z tym że już w III dekadzie czerwca notowano całkowity brak opadów, który spowodował przejście od silnego uwilgotnienia gleby po skrajną suszę w I dekadzie lipca. Ponadto w lipcu utrzymywały się dzienne temperatury powietrza powyżej $35^{\circ} \mathrm{C}$, które wpłynęły na słabsze wykształcanie ziaren w kłosach i nasion w strąkach. W trzeciej dekadzie lipca, ponowne opady $(51,5 \mathrm{~mm})$, przedłużyły wegetację roślin oraz spowodowały opóźnienie terminu zbioru (tab. 2).

W 2011 roku wegetacja roślin na Dolnym Śląsku rozpoczęła się w II dekadzie marca, w której to średnia temperatura powietrza $\mathrm{w}$ Pawłowicach wyniosła $6^{\circ} \mathrm{C}$ (tab. 3). W tym samym okresie odnotowano silne opady, przekraczające miesięczną sumę opadów $\mathrm{z}$ wielolecia 1976-2005. Jednak warunki termiczno-wilgotnościowe pozwoliły na rozpoczęcie prac polowych 20.03.2011 r. i założenie doświadczenia 22.03.2011 r. Wschody roślin pszenżyta i łubinu żółtego dzięki wyższym temperaturom powietrza były wyrównane we wszystkich kombinacjach badawczych. 
Tabela 2. Średnie dekadowe temperatury i sumy opadów w 2010 roku

Table 2. Mean decade temperature and total precipitation in 2010 year

\begin{tabular}{|c|c|c|c|c|c|c|}
\hline Miesiąc - Month & III & IV & V & VI & VII & VIII \\
\hline \multicolumn{7}{|c|}{ Temperatura - Temperature $\left[{ }^{\circ} \mathrm{C}\right]$} \\
\hline \multicolumn{7}{|l|}{ Dekada-Decade } \\
\hline I & $-1,1$ & 7,3 & 12,4 & 18,6 & 20,9 & 19,6 \\
\hline II & 3,3 & 9,5 & 11,0 & 16,5 & 23,7 & 19,5 \\
\hline III & 9,8 & 11,3 & 14,6 & 18,5 & 19,7 & 17,9 \\
\hline $\begin{array}{l}\text { Średnia miesięczna } \\
\text { Monthly means }\end{array}$ & 4,2 & 9,3 & 12,7 & 17,9 & 21,4 & 18,9 \\
\hline $\begin{array}{l}\text { Średnie wieloletnie } \\
\text { za okres 1976-2005 } \\
\text { Multiyear means } \\
\text { for 1976-2005 }\end{array}$ & 3,7 & 8,3 & 14,1 & 16,9 & 18,7 & 17,9 \\
\hline \multicolumn{7}{|c|}{ Opady - Precipitation [mm] } \\
\hline Dekada - Decade & & & & & & \\
\hline I & 0,7 & 19,7 & 32,1 & 12,2 & 2,8 & 27,3 \\
\hline II & 18,4 & 14,0 & 75,6 & 20,7 & 24,3 & 34,2 \\
\hline III & 25,8 & 11,7 & 33,0 & - & 51,5 & 47,6 \\
\hline $\begin{array}{l}\text { Sumy miesięczne } \\
\text { Monthly sums }\end{array}$ & 44,9 & 45,4 & 140,7 & 32,9 & 78,6 & 109,1 \\
\hline $\begin{array}{l}\text { Średnie wieloletnie } \\
\text { za okres } \\
\text { 1976-2005 } \\
\text { Multiyear means } \\
\text { for } 1976-2005\end{array}$ & 31,7 & 30,5 & 51,3 & 59,5 & 78,9 & 61,7 \\
\hline
\end{tabular}

Tabela 3. Średnie dekadowe temperatury i sumy opadów w 2011 roku

Table 3. Mean decade temperature and total precipitation in 2011 year

\begin{tabular}{|c|c|c|c|c|c|c|}
\hline Miesiąc - Month & III & IV & $\mathrm{V}$ & VI & VII & VIII \\
\hline \multicolumn{7}{|c|}{ Temperatura - Temperature $\left[{ }^{\circ} \mathrm{C}\right]$} \\
\hline \multicolumn{7}{|c|}{\begin{tabular}{l|l} 
Dekada - Decade & \\
\end{tabular}} \\
\hline I & 0,3 & 11,4 & 10,2 & 20,5 & 18,1 & 19,3 \\
\hline II & 6,0 & 9,7 & 16,0 & 18,7 & 20,3 & 19,4 \\
\hline III & 7,3 & 14,6 & 17,9 & 18,2 & 16,4 & 19,1 \\
\hline $\begin{array}{l}\text { Średnia miesięczna } \\
\text { Monthly means }\end{array}$ & 4,4 & 11,9 & 14,8 & 19,1 & 18,2 & 19,3 \\
\hline $\begin{array}{l}\text { Średnie wieloletnie } \\
\text { za okres } 1976-2005 \\
\text { Multiyear means } \\
\text { for } 1976-2005\end{array}$ & 3,8 & 8,3 & 14,1 & 16,9 & 18,7 & 17,9 \\
\hline \multicolumn{7}{|c|}{ Opady - Precipitation [mm] } \\
\hline \multicolumn{7}{|l|}{ Dekada - Decade } \\
\hline I & 3,1 & 10,5 & 20,3 & 33,4 & 54,7 & 14,1 \\
\hline II & 40,7 & 4,0 & 17,4 & 3,1 & 34,7 & 34,9 \\
\hline III & 1,4 & 12,5 & 11,7 & 59,2 & 81,5 & 29,9 \\
\hline $\begin{array}{l}\text { Sumy miesięczne } \\
\text { Monthly sums }\end{array}$ & 45,2 & 27,0 & 49,4 & 95,7 & 170,9 & 78,9 \\
\hline $\begin{array}{l}\text { Średnie wieloletnie } \\
\text { za okres 1976-2005 } \\
\text { Multiyear means } \\
\text { for 1976-2005 }\end{array}$ & 31,7 & 30,5 & 51,3 & 59,5 & 78,9 & 61,7 \\
\hline
\end{tabular}

$\mathrm{Na}$ początku maja wystąpiły przymrozki oraz opady śniegu, co nie wpłynęło korzystnie na dalszy rozwój roślin, gdyż opóźniło wystąpienie kolejnych faz rozwojowych. Również opady w lipcu, przekraczające miesięczną sumę opadów z wielolecia o ponad 100\%, miały niekorzystny wpływ na rozwój pszenżyta i łubinu, gdyż podobnie jak w pierwszym roku badawczym spowodowały opóźnienie terminu dojrzewania oraz zbioru.

Średnie miesięczne temperatury w sezonie wegetacyjnym 2011 były wyższe od średnich z wielolecia 19762005, z wyjątkiem lipca, w którym średnia była nieco niższa. Z kolei miesięczne sumy opadów podczas wegetacji roślin łubinu żółtego i pszenżyta jarego w kwietniu i maju były nieznacznie niższe od średnich $\mathrm{z}$ wielolecia 1976-2005, natomiast w pozostałych miesiącach odnotowano wyższe wartości.

Tabela 4. Średnie dekadowe temperatury i sumy opadów w 2012 roku

Table 4. Mean decade temperature and total precipitation in 2012 year

\begin{tabular}{|c|c|c|c|c|c|c|}
\hline Miesiąc - Month & III & IV & $\mathrm{V}$ & VI & VII & VIII \\
\hline \multicolumn{7}{|c|}{ Temperatura - Temperature $\left[{ }^{\circ} \mathrm{C}\right]$} \\
\hline \multicolumn{7}{|c|}{\begin{tabular}{|l|l} 
Dekada - Decade & \\
\end{tabular}} \\
\hline $\mathrm{I}$ & 1,9 & 5,6 & 16,1 & 14,4 & 22,4 & 20,4 \\
\hline II & 7,8 & 8,2 & 13,1 & 18,5 & 17,4 & 18,1 \\
\hline III & 8,4 & 15,5 & 18,0 & 18,9 & 20,3 & 19,5 \\
\hline $\begin{array}{l}\text { Średnia miesięczna } \\
\text { Monthly means }\end{array}$ & 6,1 & 9,8 & 15,8 & 17,3 & 20,0 & 19,3 \\
\hline $\begin{array}{l}\text { Średnie wieloletnie } \\
\text { za okres 1976-2005 } \\
\text { Multiyear means } \\
\text { for } 1976-2005\end{array}$ & 3,8 & 8,3 & 14,1 & 16,9 & 18,7 & 17,9 \\
\hline
\end{tabular}

\begin{tabular}{l|c|c|c|c|c|c}
\hline \multicolumn{7}{c}{ Opady - Precipitation [mm] } \\
\hline Dekada - Decade & \multicolumn{7}{|c}{} \\
\hline I & 4,0 & 3,4 & 49,2 & 25,7 & 42,8 & 37,6 \\
\hline II & 1,8 & 23,7 & 6,5 & 59,5 & 38,5 & 8,7 \\
\hline III & 7,9 & 0,5 & 8,0 & 9,5 & 26,7 & 26,9 \\
\hline $\begin{array}{l}\text { Sumy miesięczne } \\
\text { Monthly sums }\end{array}$ & 13,7 & 27,6 & 63,7 & 94,7 & 108,0 & 73,2 \\
\hline $\begin{array}{l}\text { Średnie wieloletnie } \\
\text { za okres 1976-2005 } \\
\begin{array}{l}\text { Multiyear means } \\
\text { for 1976-2005 }\end{array}\end{array}$ & 31,7 & 30,5 & 51,3 & 59,5 & 78,9 & 61,7 \\
\hline
\end{tabular}

Rozpoczęcie wegetacji wiosennej w 2012 roku przypadło podobnie, jak w roku poprzednim, na II dekadę marca (tab. 4). Wysiewu komponentów mieszanek zbożowo-strączkowych dokonano w warunkach słabego uwilgotnienia gleby, co skutkowało wydłużeniem faz kiełkowania i wschodów pszenżyta, a szczególnie łubinu żółtego. Krótka poprawa warunków wilgotnościowych nastąpiła w II dekadzie kwietnia, przy jednocześnie wyższych średnich temperaturach powietrza. Formowanie pędów łubinu i strzelanie w źdźbło pszenżyta oraz dalszy rozwój fazowy obydwu komponentów mieszanek przebiegły od maja do sierpnia w warunkach nadmiaru opadów, w po- 
równaniu do średnich z wielolecia 1976-2005 oraz przy wyższych średnich temperaturach powietrza. Układ warunków wilgotnościowo-termicznych w 2012 roku podobnie, jak w poprzednich sezonach wegetacyjnych, spowodował przedłużenie faz wykształcania i dojrzewania strąków u łubinu żółtego oraz dojrzewania ziarniaków pszenżyta.

We wszystkich latach badań ocenę porażenia powierzchni korzeni i podstawy źdźbła pszenżyta jarego przez patogeny wywołujące kompleks chorób podstawy źdźbła przeprowadzono w fazie dojrzałości mlecznej ziarniaków, w warunkach silnego uwilgotnienia gleby, a wyniki przedstawiono $\mathrm{w}$ postaci średnich $\mathrm{z}$ wielolecia badawczego.

Wzbogacenie biocenozy pola uprawnego sprzyja często ograniczeniu przenoszenia patogenów pomiędzy roślinami tego samego gatunku. Boligłowa i Klima (2010) zaobserwowali lepszy stan zdrowotny pszenżyta uprawianego $\mathrm{w}$ mieszankach $\mathrm{z}$ innymi zbożami $\mathrm{w}$ porównaniu do uprawy w siewie czystym.

Również Kostrzewska i wsp. (2009) odnotowali zmniejszenie występowania chorób liści jęczmienia jarego, a szczególnie plamistości siatkowej w uprawie mieszanej tego gatunku z grochem siewnym.

Tabela 5. Indeks porażenia podstawy źdźbeł pszenżyta jarego [\%] Table 5. Infection index of spring triticale culms base [\%]

\begin{tabular}{c|c|c|c}
\hline \multirow{2}{*}{$\begin{array}{c}\text { Udział pszenżyta } \\
\text { Share of triticale } \\
{[\%]}\end{array}$} & \multicolumn{3}{|c}{$\begin{array}{c}\text { Odmiana łubinu żółtego } \\
\text { Yellow lupine cultivar }\end{array}$} \\
\cline { 2 - 4 } & Dukat & Mister & $\begin{array}{c}\text { średnio } \\
\text { mean }\end{array}$ \\
\hline 50 & 9,9 & 10,00 & 10,0 \\
73 & 16,6 & 11,6 & 14,1 \\
86 & 14,2 & 16,1 & 15,1 \\
94 & 16,2 & 17,7 & 16,9 \\
100 & 18,0 & 21,9 & 20,0 \\
\hline NIR $(0,05)-$ LSD $(0.05)$ & r.n. & 2,4 & 3,0 \\
\hline Średnio - Mean & 15,0 & 15,5 & - \\
\hline NIR $(0,05)-$ LSD $(0.05)$ & \multicolumn{3}{|c}{ r.n. } \\
\hline
\end{tabular}

r.n. - różnica nieistotna - not significant difference

W wyniku przeprowadzonych badań stwierdzono istotny wpływ składu wysiewanej mieszanki na średni indeks porażenia źdźbeł pszenżyta jarego przez patogeny powodujące kompleks chorób podstawy źdźbła (tab. 5). W mieszance z najmniejszym udziałem rośliny zbożowej i największym łubinu indeks porażenia podstawy źdźbeł pszenżyta był najmniejszy, tj. dwukrotnie mniejszy od określonego w siewie czystym pszenżyta, w którym porażenie podstawy źdźbeł było najwyższe (20,0\%). Należy zaznaczyć, że już minimalny udział rośliny strączkowej w mieszance w odniesieniu do siewu czystego poprawiał istotnie zdrowotność komponentu zbożowego, średnio o 3,1\%. Według Michalskiego i wsp. (2000) pozytywny efekt rośliny towarzyszącej zależy od jej udziału w zasiewie. Podobną zależność odnotowano w odniesieniu do poszczególnych odmian, chociaż dla odmiany Dukat były to różnice nieistotne statystycznie. Nie stwierdzono natomiast wpływu odmiany łubinu żółtego na indeks porażenia podstawy źdźbeł pszenżyta jarego.

Również indeks porażenia korzeni pszenżyta jarego zależał istotnie od liczby wysianych nasion/ziarna obu komponentów stanowiących mieszanki (tab. 6). Najniższą średnią jego wartość $(9,8 \%)$ odnotowano w mieszance z udziałem 80 sztuk nasion łubinu i 80 sztuk ziaren pszenżyta, a najwyższą $\mathrm{w}$ mieszance $\mathrm{z}$ największym udziałem zboża oraz w uprawie tego gatunku w siewie czystym. Należy zaznaczyć, że odmiennie niż przy porażeniu źdźbeł, w mieszance $\mathrm{z}$ najmniejszym udziałem rośliny strączkowej nie stwierdzono poprawy zdrowotności pszenżyta, lecz nawet obserwowano nieznacznie większy indeks porażenia jego korzeni. Dopiero mieszanka z 73 procentowym udziałem pszenżyta (60 nasion łubinu i 160 ziaren pszenżyta) istotnie poprawiła zdrowotność systemu korzeniowego pszenżyta o $2,9 \%$ w porównaniu do zasiewu czystego. Podobną zależność odnotowano w mieszankach poszczególnych odmian, chociaż dla odmiany Dukat istotnie mniejsze porażenie korzeni pszenżyta obserwowano już w mieszance z 86 procentowym udziałem rośliny zbożowej. Analogicznie, jak przy porażeniu źdźbeł, nie stwierdzono istotnych zmian w porażeniu korzeni pszenżyta jarego w zależności od zastosowanej odmiany łubinu żółtego.

Tabela 6. Indeks porażenia korzeni pszenżyta jarego [\%] Table 6. Infection index of spring triticale roots [\%]

\begin{tabular}{c|c|c|c}
\hline \multirow{2}{*}{$\begin{array}{c}\text { Udział pszenżyta } \\
\text { Share of triticale } \\
{[\%]}\end{array}$} & \multicolumn{3}{|c}{ Odmiana łubinu żółtego } \\
& Yellow lupine cultivar \\
\cline { 2 - 4 } & Dukat & Mister & $\begin{array}{c}\text { średnio } \\
\text { mean }\end{array}$ \\
\hline 50 & 10,9 & 8,6 & 9,8 \\
73 & 11,1 & 10,6 & 10,8 \\
86 & 9,3 & 15,4 & 12,4 \\
94 & 16,6 & 12,3 & 14,4 \\
100 & 13,3 & 14,0 & 13,7 \\
\hline NIR $(0,05)-$ LSD $(0.05)$ & 3,4 & 3,0 & 1,9 \\
\hline Średnio - Mean & 12,3 & 12,2 & - \\
\hline NIR $(0,05)-$ LSD $(0.05)$ & \multicolumn{3}{|c}{ r.n. } \\
\hline
\end{tabular}

r.n. - różnica nieistotna - not significant difference

Zbliżone wyniki odnotowała Pląskowska i wsp. (2000) stwierdzając ograniczenie występowania chorób podstawy źdźbła u jęczmienia jarego wysiewanego w mieszankach z łubinem wąskolistnym. Wenda-Piesik i Rudnicki (2000) nie odnotowali natomiast istotnego wpływu uprawy współrzędnej pszenżyta jarego z grochem siewnym na zmniejszone występowanie chorób podstawy źdźbła, chociaż zaobserwowali, że w uprawach mieszanych porażenie korzeni pszenżyta było mniejsze. Kostrzewska i wsp. (2009) twierdzą natomiast, że wprawdzie uprawa jęczmienia w mieszance $\mathrm{z}$ grochem ogranicza występowanie chorób grzybowych liści u gatunku zbożowego, ale jednocześnie powoduje wzrost występowania chorób podsuszkowych. 


\section{Wnioski / Conclusions}

1. Indeks porażenia podstawy źdźbeł pszenżyta jarego przez patogeny powodujące kompleks chorób podstawy źdźbła w każdej z ocenianych mieszanek z łubinem żółtym był niższy niż w siewie czystym. Już minimalny udział gatunku strączkowego $\mathrm{w}$ mieszance poprawiał istotnie zdrowotność komponentu zbożowego.

2. Indeks porażenia korzeni pszenżyta jarego również zależał istotnie od ilości wysiewu obu komponentów, chociaż dopiero mieszanka z 73 procentowym udzia- łem pszenżyta (60 nasion łubinu i 160 ziaren pszenżyta), w stosunku do siewu czystego, istotnie poprawiła zdrowotność korzeni pszenżyta.

3. Nie odnotowano istotnego wpływu badanych odmian łubinu żółtego na porażenie podstawy źdźbeł i korzeni pszenżyta jarego przez patogeny powodujące kompleks chorób podstawy źdźbła.

Zadanie współfinansowane przez Unię Europejską w ramach Europejskiego Funduszu Społecznego.

\section{Literatura / References}

Bartkowiak A. 1978. Analiza wariancji dla układów ortogonalnych. Program awa. s. 43-60. W: „Opis merytoryczny programów statystycznych opracowanych w Instytucie Informatyki Uniwersytetu Wrocławskiego” (A. Bartkowiak, red.). Wyd. Uniwersytetu Wrocławskiego, Wrocław, 168 ss.

Boligłowa E., Klima K. 2010. Zdrowotność pszenżyta jarego w uprawie ekologicznej i konwencjonalnej. [Healthiness of spring triticale in ecological and conventional systems]. Prog. Plant Prot./Post. Ochr. Roślin 50 (2): 615-619.

GUS 2012. Roczniki statystyczne rolnictwa. Główny Urząd Statystyczny, Warszawa.

Kostrzewska M.K., Wanic M., Kurowski T.P., Okorski A., Nowicki J. 2009. Zdrowotność jęczmienia jarego w siewie czystym i mieszanym z grochem siewnym. Fragm. Agron. 26 (3): 68-75.

Małecka I., Blecharczyk A., Sawinska Z., Hagedorn M. 2010. Wpływ przedplonu i nawożenia na zdrowotność pszenżyta ozimego $\mathrm{w}$ doświadczeniu wieloletnim. [Impact of previous crop and fertilization on health of winter triticale in long-term experiment]. Prog. Plant Prot./Post. Ochr. Roślin 50 (2): 935-938.

Michalski T., Weber Z., Gołębniak B., Osiecka B., Bieliński S. 1996. Uprawa mieszanek jako agrotechniczna metoda ochrony zbóż przed chorobami. [Growing of cereal mixtures as on agrotechnical method of their protection against diseases]. Prog. Plant Prot./Post. Ochr. Roślin 36 (1): 229-235.

Michalski T., Weber Z., Gołębniak B. 2000. Occurrence of diseases on triticale and barley plants grown in pure stands and their mixtures. J. Plant Prot. Res. 40 (3/4): 198-204.

Paluch M., Parylak D. 2011. Wpływ zabiegów proekologicznych w monokulturze pszenżyta ozimego na ograniczenie porażenia przez choroby podsuszkowe. [Effect of eco-friendly measures in winter triticale monoculture on the reduction of infection by steam base diseases]. Prog. Plant Prot./Post. Ochr. Roślin 51 (3): 1328-1334.

Parylak D., Paluch M., Wojtala-Łozowska L. 2010. Ocena możliwości ograniczania porażenia pszenżyta ozimego uprawianego po sobie przez choroby podstawy źdźbła. [Possibilities of stem base diseases limitation in winter triticale continuous crop]. Prog. Plant Prot./Post. Ochr. Roślin 50 (2): 695-699.

Pląskowska E., Kita W., Matkowski K. 2000. Badania zdrowotności jęczmienia jarego (Hordeum vulgare L.) i łubinu wąskolistnego (Lupinus angustifolius L.) uprawianych w siewie czystym i mieszankach. Zesz. Nauk. AR Wrocław 396, Rol. 77: 111-124.

Townsend G.R., Heuberger J.V. 1943. Methods for estimating losses caused by diseases in fungicide experiments. Plant Dis. Rep. 27: $340-343$

Tratwal A., Wielkopolan B., Bocianowski J. 2012. Znaczenie mieszanek międzyodmianowych w ograniczaniu porażenia pszenicy ozimej przez mączniaka prawdziwego. Pol. J. Agron. 10: 30-35.

Wenda-Piesik A., Rudnicki F. 2000. Występowanie niektórych agrofagów pszenżyta jarego uprawianego w siewie czystym i w mieszankach. Folia Univ. Agric. Stetin. 206, Agricultura 82: 303-310. 